\title{
A Strategic Functional Theory of Institutions and Rethinking Asian Regionalism
}

\author{
When Do Institutions Matter?
}

\begin{abstract}
Institutions do not always matter. They can make it easier for states to deal with nontraditional security threats and alleviate arms races, but they are less likely to matter in dealing with territorial disputes and negotiating multilateral trade agreements. We should neither overestimate nor underestimate the utility of ASEAN-centered regionalism in the Asia Pacific.
\end{abstract}

KEYWORDS: regionalism, multilateralism, ASEAN, functional theory, game theory

\section{INTRODUCTION}

Since the end of the Cold War, the institutionalization of international politics has become one of the most stunning phenomena in world politics. While the economic and political integration of Europe attracts worldwide praise, the development of regionalism in the Asia Pacific receives mixed appraisals. On the one hand, the proliferation of international institutions in the Asia Pacific makes it hard to deny their importance in regional international relations. ${ }^{1}$ On the other hand, scholars and pundits are both frustrated and critical of the ineffectiveness of Asia's multilateral institutions in addressing economic and political challenges there. ${ }^{2}$

KaI HE is Associate Professor of Political Science at the University of Copenhagen. He is the author of Institutional Balancing in the Asia Pacific (2009) and co-author of Prospect Theory and Foreign Policy Analysis in the Asia Pacific (2013). The author would like to thank Huiyun Feng, Hiro Katsumata, Sheldon Simon, See Seng Tan, Stephen Walker, and an anonymous reviewer for their support and suggestions. All errors are the author's own. Email: <hekai@yahoo.com>.

I. Anthony Smith, "ASEAN's Ninth Summit: Solidifying Regional Cohesion, Advancing External Linkages," Contemporary Southeast Asia 26:3 (December 2004), pp. 416-33; Rodolfo Severino, "ASEAN Beyond Forty: Toward Political and Economic Integration," Contemporary Southeast Asia 29:3 (December 2007), pp. 406-23.

2. Michael Leifer, "The ASEAN Peace Process: A Category Mistake," Pacific Review I2:I (April 1999), pp. 25-39; David Jones and Michael Smith, "Making Process, Not Progress: ASEAN and the

Asian Survey, Vol. 54, Number 6, pp. II84-I208. ISSN ooo4-4687, electronic ISSN I533-838X. @ 2014 by the Regents of the University of California. All rights reserved. Please direct all requests for permission to photocopy or reproduce article content through the University of California Press's Rights and Permissions website, http://www.ucpressjournals.com/reprintInfo.asp. DOI: I0.I525/AS.20I4.54.6.II84. 
Through engaging this theoretical debate over the role of institutions in Asian international relations, this paper suggests that neither unconditional praise nor wholesale criticism of Asian regionalism is warranted. Instead of debating over whether and how institutions matter in the Asia Pacific, it is more important to examine when institutions matter. Challenging prevailing arguments of realism, neoliberal institutionalism, and constructivism in the study of institutions, I introduce a strategic functional theory of institutions to explain their diverse roles in various strategic settings in world politics.

The strategic functional theory suggests that the functions of institutions are constrained and shaped by two strategic factors: strategic uncertainty and conflicts of interest between states regarding a specific issue-area. Specifically, there are four types of issue-areas defined by these two factors operating at varying intensities: territorial disputes, arms races, non-traditional security threats, and international trade negotiations. In this paper, I illustrate and model these four types of issues with four well-known games: the game of Chicken (territorial disputes), the Prisoner's Dilemma (arms races), the Stag Hunt (non-traditional security threats), and the Battle of the Sexes (international trade negotiations).

Borrowing insights from game theory, I argue that institutions are more likely to matter in dealing with non-traditional security threats (the Stag Hunt game) and in alleviating arms races (the Prisoner's Dilemma game), in which institutions can help reduce strategic uncertainties between states. A binding and contracting type of institution is needed to enforce agreements to alleviate arms races between states. Loosely organized and conventionbased institutions are also sufficient for two states to cooperate in coping with non-traditional security threats, as long as the institutions can provide necessary information and suggest a focal point for cooperation.

However, institutions are less likely to matter when dealing with territorial disputes (the game of Chicken) and negotiating international trade agreements (the Battle of the Sexes) between two states. Although institutions can still provide information and reduce transaction costs, the key issue in both

\footnotetext{
Evolving East Asian Regional Order,” International Security 32:I (Summer 2007), pp. I48-84; Donald Emmerson, "Challenging ASEAN: A 'Topological' View," Contemporary Southeast Asia 29:3 (December 2007), pp. 424-46; John Ravenhill, "East Asian Regionalism: Much Ado About Nothing?” Review of International Studies 35:SI (February 2009), pp. 215-35.
} 
games is the uneven distributional gains either on sovereignty issues or on trade benefits. Therefore, institutions become insufficient to solve this distribution problem. Instead, material power can play a more important role in helping states either to accept different payoffs in trade negotiations or to avoid worst outcomes in territorial disputes.

\section{DEBATING ASIAN REGIONALISM}

Since the end of the Cold War, multilateral institutions have emerged as one of the most salient players in the international relations of the Asia Pacific. Most Asian states have actively participated at different levels in various multilateral institutions such as the Association of Southeast Asian Nations (ASEAN), the Asian Pacific Economic Cooperation (APEC), the ASEAN Regional Forum (ARF), the ASEAN Plus Three (APT), and the East Asia Summit (EAS). ASEAN has become the center of gravity of regionalism in the Asia Pacific since the mid-rg9os.

Scholarly debates over the role of Asian regionalism have mainly focused on how ASEAN and ASEAN-centered institutions matter. Rationalists, in general, suggest that multilateral institutions serve as an intervening variable to connect state interests and policy outcomes. ${ }^{3}$ For example, Marc Lanteigne suggests that China used multilateral institutions such as ARF as a diplomatic tool to pursue its great-power status after the Cold War. ${ }^{4}$ Kai He argues that states in the Asia Pacific have engaged in institutional balancing through multilateral institutions to constrain each other's influence and power since the end of the Cold War. ${ }^{5}$ Jürgen Rüland points out that ASEAN's multilateral behavior is actually closer to a "hedging utility" than a "multilateral utility," and this realist-driven policy constrains its willingness and capacity to deepen institutions and solve real problems. ${ }^{6}$

3. Robert Keohane, After Hegemony: Cooperation and Discord in the World Political Economy (Princeton, N. J.: Princeton University Press, 1984); Robert Keohane, and Lisa Martin, "The Promise of Institutionalist Theory," International Security 20:I (Summer 1995), pp. 39-5I.

4. Marc Lanteigne, China and International Institutions: Alternative Paths to Global Power (London: Routledge, 2005).

5. Kai He, Institutional Balancing in the Asia Pacific: Economic Interdependent and China's Rise (London: Routledge, 2009).

6. Jürgen Rüland, "Southeast Asian Regionalism and Global Governance: 'Multilateral Utility' or 'Hedging Utility'?” Contemporary Southeast Asia 33:I (April 20II), pp. 83-II2. 
Another group of scholars in the rationalist school, however, focuses on the functional utility of institutions in facilitating cooperation among self-interested states operating within an anarchic international system. In the study of Asian institutions, scholars normally frame the strategic situation as an assurance or coordination game, in which institutions can play a role of an "information clearinghouse" in providing a focal point for mutual cooperation between states. ${ }^{7}$ Other scholars offer a more moderate and cautious assessment on the utility of ASEAN-oriented institutions. For example, Sheldon Simon points out that there will be a "long and bumpy road [for ASEAN] to [become a] community," arguing that the greatest utility of ASEAN-oriented institutions is to provide "venues for national leaders to discuss pressing issues on the sidelines of these gatherings." because these groups lack binding and enforcement mechanisms, encouraging information exchange through dialogue and annual gatherings has become their major, if not their only, function.

Differing from rationalists who see institutions as either strategic or functional utilities for states to pursue interests, the constructivist school argues that institutions can constitute, shape, and change state interests and behavior. In Southeast Asia, scholars emphasize the role of norm diffusion and identity formation in building multilateral institutions and shaping regional order. Particularly, the ASEAN Way and the non-interference principle are two distinctive norms cherished by ASEAN states in practice, as well as by constructivist scholars in research. For example, Amitav Acharya suggests that the ASEAN Way, "the process of regional interactions and cooperation based on discreteness, informality, consensus building, and non-confrontational bargaining styles," has fostered a unique and shared "we" feeling, a regional identity for Southeast Asian states. ${ }^{9}$ In addition, the ASEAN Way has the

7. Tsuyoshi Kawasaki, "Neither Skepticism nor Romanticism: The ASEAN Regional Forum as a Solution for the Asia Pacific Assurance Game," Pacific Review 19:2 (August 2006), pp. 219-37; Hidetaka Yoshimatsu, "Collective Action Problems and Regional Integration in ASEAN," Contemporary Southeast Asia 28:I (April 2006), pp. II5-40.

8. Sheldon Simon, "ASEAN and Multilateralism: The Long, Bumpy Road to Community," Contemporary Southeast Asia 30:2 (August 2008), p. 264.

9. Amitav Acharya, Constructing a Security Community in Sea: ASEAN and the Problem of Regional Order (London: Routledge, 200I), p. 64; also Nikolas Busse, "Constructivism and Southeast Asian Security," Pacific Review I2:I (April i999), pp. 39-6o. 
potential to be transformed into an "Asia-Pacific Way" through socialization and institution-building processes. ${ }^{10}$

Acharya argues that ASEAN is not a simple "norm taker" of prevailing global norms and ideas. Instead, ASEAN plays an active role in localizing, transforming, and modifying global norms to fit regional normative beliefs and practices. ${ }^{11}$ Therefore, its adherence to the non-interference principle is seen as a normative product of norm selection and localization by ASEAN states. Precisely because of these unique norms and shared identity, ASEANoriented regionalism, according to constructivists, is different from Westernstyle regionalism in Europe. For constructivists, the post-Cold War peaceful environment in Southeast Asia in particular and in the Asia Pacific in general is attributed to the shared identity, institution-building, and norm diffusion driven by ASEAN. In particular, both China and the U.S. have been successfully socialized and enmeshed by ASEAN's norms and rules operating through multilateral institutions. ${ }^{12}$ In the same vein, Hiro Katsumata implicitly suggests that the ARF is equipped to address the South China Sea disputes because China has been learning cooperative security norms in the ARF. ${ }^{13}$

Although the scholarly debates between rationalists and constructivists can enrich and deepen our understanding on how ASEAN-centered institutions matter, there are four theoretical and empirical deficiencies in the study of multilateral institutions in the Asia Pacific. First, institutional realists may be right to suggest that states can rely on institutions to pursue interests. However, why states use institutions, why ASEAN—a group of small and middle powers - can take the lead, and how institutions can constrain state policy choices are still unsolved puzzles for institutional realists. It is true that some scholars have suggested that economic interdependence is a necessary condition for states to conduct institutional balancing through multilateral

Io. Amitav Acharya, "Ideas, Identity, and Institution Building from the 'ASEAN Way' to the 'Asia-Pacific Way'?" ibid., IO:3 (1997), pp. 319-46.

II. Idem, "How Ideas Spread: Whose Norms Matter? Norm Localization and Institutional Change in Asian Regionalism,” International Organization 58:2 (April 2004), pp. 239-75.

I2. Evelyn Goh, "Great Powers and Hierarchical Order in Southeast Asia: Analyzing Regional Security Strategies," International Security 32:3 (Winter 2007), pp. II3-57; Amitav Acharya, "Do Norms and Identity Matter? Community and Power in Southeast Asia's Regional Order," Pacific Review I8:I (2005), pp. 95-II8.

I3. Hiro Katsumata, ASEAN's Cooperative Security Enterprise (Basingstoke: Palgrave MacMillan, 2009). 
institutions; ${ }^{14}$ moreover, strategic uncertainties, especially the competition among the U.S., China, and Japan, offer a strategic opportunity for ASEAN to lead the institution-building process in the post-Cold War Asia Pacific. ${ }^{15}$ However, the problem for institutional realists lies in their one-way-street approach to analyzing how states utilize institutions without paying enough attention to how institutions may also constrain and influence states' policy choices.

Second, rational functionalists fail to explain why the assurance or coordination game is the accurate strategic specification in the Asia Pacific after the Cold War. In order to show the functional value of ASEAN and ASEANcentered institutions, rational functionalists normally frame post-Cold War Asia as a coordination or assurance game, in which strong enforcement and legalistic mechanisms are not necessary for state cooperation. It seems that ASEAN's loosely designed, consensus-based institutional settings, e.g., the ASEAN Way, are compatible with this predetermined coordination game. However, as Simmons and Martin point out, this ex ante specification of strategic condition is the weakest link for rational functionalism. ${ }^{16}$ In addition, there are other types of games in game theory. Even for coordination games, how to solve the distribution problem between players remains unanswered for rational functionalists.

Third, constructivists overemphasize the constitutive role of norms and identity through socialization and institution-building processes. It may be true that ASEAN may have formed a unique identity and constructed norms among member states as a result of cultural and social interconnections. However, how the shared identity and norms can influence and shape the behavior of outside members, such as China and the U.S., is still questionable. Especially given current tensions between them, it is doubtful whether China and the U.S. have really been socialized by ASEAN's rules and norms, as constructivists optimistically suggested. In other words, how to evaluate

I4. He, Institutional Balancing in the Asia Pacific.

15. Ralf Emmers, Cooperative Security and the Balance of Power in ASEAN and ARF (London: RoutledgeCurzon, 2003); John Ravenhill, "A Three Bloc World? The New East Asian Regionalism," International Relations of the Asia Pacific 2:2 (2002), pp. 167-95; Dominik Heller, "The Relevance of the ASEAN Regional Forum (ARF) for Regional Security in the Asia Pacific," Contemporary Southeast Asia 27:I (April 2005), pp. I23-45.

16. Beth Simmons and Lisa Martin, "International Organizations and Institutions," in Handbook of International Relations, ed. by Walter Carlsnaes, Thomas Risse, and Beth Simmons (London: Sage Publications, 2002), p. 196. 
the effectiveness of norms and identity is still problematic for constructivists. Some research has suggested that even inside ASEAN, shared identity and norms play a minimal role in shaping state behavior because most ASEAN states still rely on external powers to ensure their security. ${ }^{17}$ Other critics even argue that the so-called unique norms and shared identity in Southeast Asia are just "what stronger states [external powers] make of them." ${ }_{18}$

Last, but not least, all existing research ignores the "when" question to a certain extent in discussing the role of multilateral institutions. While both rationalists and constructivists provide different rationales and mechanisms on how institutions matter, they pay little attention to specify the conditionality of institutions in world politics. For rationalists, institutions are by no means the only diplomatic tool for states to use to pursue their strategic or functional interests. In other words, states may not choose institutions under certain strategic conditions. For example, when states face imminent security threats from a malign power, multilateral institutions may not be useful in deterring external aggression. For constructivists, norms, identity, and institution-building may be able to constitute and shape state interests and behavior. However, they do not always work in all issue areas. The mere emphasis on the "process of socialization" leaves too many unknowns to the future. Therefore, the real challenge for both rationalists and constructivists is not to ask whether and how institutions matter. Instead, when and under what conditions institutions do matter, and more importantly, when they do not, deserve serious scholarly inquiry and scrutiny.

\section{A STRATEGIC FUNCTIONAL THEORY OF INSTITUTIONS}

In this paper, I introduce a strategic functional theory of institutions to specify four strategic conditions and suggest when institutions matter, as well as when they do not. The strategic functional theory of institutions is built on both institutional realism and rational functionalism. On the one hand, I assume that states are interest-driven political entities, and their strategic goals are to maximize their relative gains in a realist world. On the other

I7. Tobias Nischalke, "The ASEAN Way, a Real Spirit or a Phantom?” Contemporary Southeast Asia 22:I (April 2000), pp. 89-II2; and idem, "Does ASEAN Measure Up? Post-Cold War Diplomacy and the Idea of Regional Community," Pacific Review I5:I (2002), pp. 89-II7.

I8. Jones and Smith, "Making Process, Not Progress." 
hand, I assume that institutions can facilitate states' pursuit of their realist goals, only under certain strategic conditions.

One caveat is worth noting. These two assumptions about states' interests and institutions may or may not reflect reality in world politics. Besides interests, their own identity, historical experience, and norms may also play important roles in shaping state behavior. For example, Canada's military modernization may not be seen as a threat in the eyes of American policymakers. ${ }^{19}$ However, in order to construct a parsimonious, general, and middle-range model, this research will follow the common assumptions of realism, which assumes that all states are security-driven and living under international anarchy. Following Robert Keohane, ${ }^{20} \mathrm{I}$ am experimenting with the first-cut theorization of different functions of institutions, intending to offer a straightforward and parsimonious explanation of when institutions matter in world politics. Other schools of thought, such as liberalism and constructivism, can offer insights and suggestions that complement and sharpen our understanding of multilateral institutions.

Borrowing the theoretical framework of rational functionalists, I use four notable games from game theory to illustrate four types of strategic situations in world politics. These four games are neither exhaustive nor exclusive in nature. They are just simple illustrations of the strategic logics in the theory and are intended to set a foundation for other scholars to apply when modeling strategic situations in the future.

I argue that two strategic factors, strategic uncertainty and the conflictinginterests of issues, shape the nature of strategic situations that states face in world politics. Strategic uncertainty is measured by how certain it is for a state to know about its rival's intentions and behavior. This can be low or high. While low strategic uncertainty means that the state is pretty sure about what its rival will do or wants to do, high strategic uncertainty indicates a large degree of unpredictability in its rival's actions. For example, a state's behavior in territorial disputes contains a low level of uncertainty because sovereign claims should not have any ambiguity, and a state should know what its rival wants and will do over a disputed territory in the future. On the contrary,

19. I acknowledge one reviewer's suggestion. Alexander Wendt used a similar example; see Alexander Wendt, "Anarchy Is What States Make of It: The Social Construction of Power-Politics," International Organization 46:2 (Spring 1992), pp. 39I-425.

20. Robert Keohane, Neorealism and Its Critics (New York: Columbia University Press, 1986), pp. $158-203$. 
FIGURE I. Strategic Functional Theory of Institutions in Game Theory Typology

Strategic Uncertainty

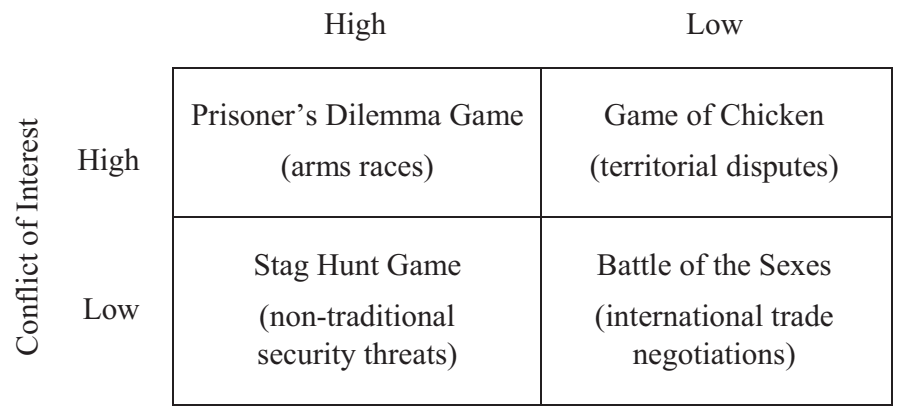

SOURCE: By author.

a state's military modernization program is difficult to evaluate because it can be either for self-defense purposes or offensive in nature.

The conflict of interests is gauged by how difficult it is for states to share equal interest on an issue of concern. This can be either high or low. A low conflict-of-interest issue refers to an issue in which two states share a common interest. A high conflict-of-interest issue means that they have uncompromisable interests regarding a given issue. For example, territorial disputes are widely seen as an issue with a high conflict of interest, because state sovereignty is exclusive in nature. On the other hand, transnational crimes are a low conflict-of-interest issue because states have a shared interest in fighting international criminal activities.

Based on the interplay between strategic uncertainty and the conflict-ofinterest nature of different issues, states face four types of strategic situations. Using four popular games in game theory, we can illustrate these four issues as the Prisoner's Dilemma game (military modernization/arms race), the game of Chicken (territorial disputes), the Stag Hunt game (non-traditional security threats), and the Battle of the Sexes (international trade negotiations). Figure I shows these four games and the corresponding examples in world politics.

\section{The Prisoner's Dilemma Game-Military Modernization and Arms Races}

The Prisoner's Dilemma (PD) is a well-known problem of collective action. It is also a collaboration problem, in which both players will not cooperate 
FIGURE 2. Prisoner's Dilemma under High Uncertainty and High Conflict of Interest

Criminal 2

\begin{tabular}{|c|c|c|}
\hline & Quiet & Talk \\
\hline Quiet & 2,2 & 0,3 \\
\hline Talk & 3,0 & $\underline{1,1}$ \\
\hline
\end{tabular}

SOURCE: <www.gametheory.net>.

NOTE: One Pure Nash equilibrium is underlined.

because of their dominant, self-interested strategy, even though they know that cooperation will make both of them better off. Figure 2 shows a payoff matrix of the PD game. The simple version of the story is that two criminals are arrested and placed in separate cells. The police give them two options: be quiet or talk. If they both stay quiet, then each will be convicted of a minor offense. The payoff for them is $(2,2)$. If one talks and the other stays quiet, then the one who talks will be freed and used as a witness against the other, who will be given a life sentence. The payoffs for both criminals are either $(0,3)$ or $(3,0)$, in which the freed one has the highest payoff of 3 . If they both talk, then both will be convicted of major crimes. The payoffs for them are $(\mathrm{I}, \mathrm{I}) .^{21}$

In this PD game, each criminal has a dominant strategy of "talk" because no matter what the other does, "talk" will give him the higher payoff. There is only one Nash equilibrium in this game, in which both criminals will choose

2I. Payoffs are numbers simply ranking the desirability of outcomes for players. In the PD game, for example, the payoffs for each criminal rank as o, I, 2, and 3. While o is the least desirable outcome (i.e., to receive a life sentence), 3 refers to the most desirable outcome (i.e., to go free without a charge). I and 2 indicate the two ranked options in-between, i.e., major crime for I and minor offense for 2. In a game matrix, each cell has two numbers representing the payoffs for each player in the game. The first number represents the payoff to the row player (in this case Criminal I), and the second number represents the payoff to the column player (in this case Criminal 2). Therefore, cell $(2,2)$ means that both criminals will receive a payoff of 2 (minor offense) if both of them take the action of "quiet." See <www.gametheory.net>. 
to talk. "Talk" is a self-interested and rational decision for both players in the game because (I) if Criminal 2 chooses to remain "quiet," Criminal I will go free by "talking" (with a payoff of 3); (2) if Criminal 2 also talks, Criminal I will be convicted of a major crime with a payoff of $\mathrm{I}$, but this outcome is still better than a life sentence (payoff of o). However, from the payoff matrix, we can see that if both players stay "quiet," they will be better off $(2,2)$.

Although the PD game is widely used by political scientists to illustrate a problem of collective action, few studies examine when and under what conditions the PD is more likely to happen. The theory of strategic action in this paper suggests that two strategic factors, high uncertainty and high conflict of interest, shape a PD game situation. Since both criminals do not know what the other will do, they have to make the worst-case assumption about the other's behavior. It is a high strategic uncertainty situation. In terms of interests, both criminals want to be freed. The only way to be freed is to talk, i.e., to sell out the other, and hope that the other will stay quiet. Therefore, the conflict-of-interest level between the two criminals is high.

In international politics, military modernization follows the logic of the PD game. If country A decides to modernize its military capabilities by purchasing more weapons, this behavior is highly uncertain in the eyes of its rival country B because B does not know what A's military modernization program really means. As mentioned earlier, such a program can be either defensive or offensive. Therefore, it is a highly uncertain situation. In addition, the strengthened military capabilities of A potentially or even directly threaten B's survival and security in the international system. Since all states are self-regarded unitary actors in an anarchic world, security or survival is the highest priority and constitutes an uncompromisable interest for states.

Therefore, as illustrated in the PD game, the dominant strategy for both states is to purchase more weapons and engage in an arms race. It is the optimal strategy or Nash equilibrium strategy for both states, in that both choose a rational decision to maximize their payoffs. However, both states also know that they will be better off if both of them can simultaneously reduce arms acquisitions, i.e., sign an arms control agreement. This will not

22. A Nash equilibrium, named after John Nash, is a set of strategies, one for each player, such that no player has incentive to unilaterally change his/her action. See ibid. 
only save money for both states but will also reduce their bilateral security threats and ease their security dilemmas. ${ }^{23}$

The PD game reveals a collaboration problem in international relations. Although states know that cooperation is good, the self-interested nature of states and a lack of information prevent them from cooperating with one another. Here, institutions can play two important roles in facilitating state cooperation. First, institutions can provide information and reduce uncertainties regarding intentions and behavior between the two states. If two criminals in the PD game are given a chance to communicate, they may reach a deal to stay quiet instead of talk. However, one unsolved issue is the degree of mutual trust. Each criminal still has the incentive to sell the other out because it will mean freedom at the expense of the other. States also have the incentive to cheat even after signing an arms control agreement, because cheating will bring them the greatest advantage if their rivals keep the commitment to reduce arms.

The mere informational exchange through institutions cannot address the commitment problem between states. Therefore, institutions can provide a second utility in the PD game- - a contracting and enforcement mechanismthrough which the cheating party will face a serious consequence or punishment. As long as a binding agreement is established and enforced by institutions, it is in both states' interests to cooperate. Institutions may also help states build up mutual trust or a common identity in the long run, as constructivists suggest. However, it is not a necessary condition for cooperation in a rationalist world. Trust and common identity can be seen as externalities of strong binding institutions.

In addition, scholars also suggest that institutions can offer an environment or opportunity for states to play the "iterated PD" game, in which states are more likely to use a "tit for tat" strategy to achieve cooperation. ${ }^{24}$ Institutions can expand the "shadow of the future" for both states and encourage them to develop reciprocal and mutually beneficial interactions because they know that today's cheating will bring them tomorrow's retaliation. ${ }^{25}$

23. Robert Jervis, "Cooperation under the Security Dilemma," World Politics 30:2 (January 1978), pp. I67-2I4.

24. Robert Axelrod, The Evolution of Cooperation (New York: Basic Books, 1984).

25. Robert Axelrod and Robert Keohane, "Achieving Cooperation under Anarchy," World Politics 38:I (October 1985), pp. 226-54. 
FIGURE 3. Stag Hunt Game under High Uncertainty and Low Conflict of Interest

Hunter 2

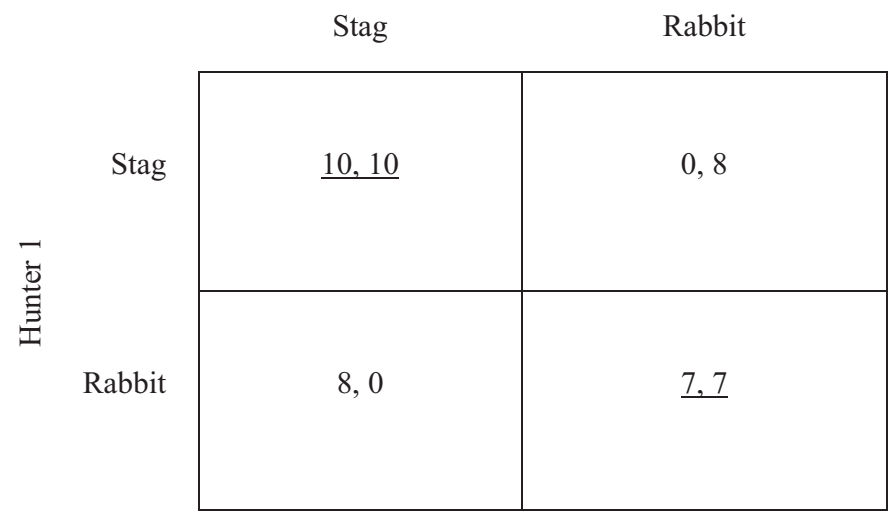

SOURCE: Ibid. to Figure 2.

NOTE: The two pure Nash equilibriums are underlined.

\section{The Stag Hunt Game-Non-Traditional Security Challenges}

The Stag Hunt game is a coordination problem in game theory. The brief story is that two hunters can either jointly hunt a stag (a large meal) or individually hunt a rabbit (tasty but less fulfilling). Hunting stags is quite challenging and requires mutual cooperation. If either hunts a stag alone, the chance of success is minimal. The payoff matrix is shown in Figure 3. We can see that if both hunters work together to hunt a stag, they can achieve the highest payoffs (Io, Io). If they work together to hunt a rabbit, the payoffs will be lower $(7,7)$. However, if they hunt alone, the chance of hunting a stag is minimal (the payoff is o), but a lucky hunter may bag a rabbit instead (8).

In this coordination game, there are two Nash equilibriums, meaning the hunters can work together to either hunt a stag or pursue a rabbit. Both hunters prefer the high payoff option, i.e., to hunt a stag together. However, it is also a risky decision for each individual hunter. If one hunter decides to hunt a stag, his payoff depends on how the other hunter does. If the other hunter also aims at a stag, then there is a happy ending. However, if the other hunter does not hunt a stag, this will leave nothing to the first hunter. In comparison, it is safe to hunt a rabbit in the first place because no matter what the other hunter does, this will put some payoff (food) on the table. Therefore, for both hunters, hunting a stag is a risky decision compared to 
pursuing a rabbit because they do not know what the other will do. In other words, both hunters still face a difficult decision as to what they should do even though they know that hunting a stag together will bring them more benefits. It is also rational for a hunter to pursue a rabbit instead of working together for a stag, given the higher risks of hunting a stag. Kenneth Waltz actually used this Stag Hunt analogy to explain why cooperation between two states is difficult in world politics even though both know that cooperation is good for them. ${ }^{26}$

The theory of strategic action presented in this paper suggests that the Stag Hunt game is shaped by two factors: high uncertainty and low conflict of interest. As mentioned above, the two hunters have no idea what the other will do in the game. However, they share a common interest in hunting a stag because it will bring them the highest payoff. This differs from the PD game, in which the two criminals have a high level of conflict-of-interest because the well-being of one criminal (freedom) is based on the worst outcome for the other.

In international politics, non-traditional security challenges fit the Stag Hunt logic. On the one hand, states do not know what the other will do to deal with non-traditional security threats such as terrorism, drug trafficking, and environmental disasters. Given the transnational nature of these threats, both states in the game know that they will not be able to deal with these problems alone, just as in the Stag Hunt, both hunters know that it is impossible to hunt a stag alone. Therefore, a highly uncertain situation has emerged. On the other hand, all states share a common interest to tackle these non-traditional threats. In addition, both states know that it is better for them to cooperate in tackling these non-traditional security issues. However, each state faces a risk in acting alone, because it may accomplish nothing if the other state does not do the same. Here, to simplify the situation, we have to assume that the probability (or the risk) of hunting a stag is similar to that of hunting a rabbit. Otherwise, as mentioned above, both hunters will pursue rabbits instead of a stag.

In the Stag Hunt game, the key is to build mutual trust so the two hunters can cooperate to hunt a stag together. In dealing with non-traditional security threats, institutions can help states resolve this Stag Hunt dilemma. First, p. 168. 
states can reduce the transaction costs and exchange information through institutions. If a non-traditional security issue is indeed urgent and all states are well aware of it, institutions can encourage states to reach a focal point for cooperation.

Besides, institutions can also expand the "shadow of the future" for both states in their interactions so that it is not a one-shot enterprise to deal with any non-traditional threats. However, binding requirements for institutions in the Stag Hunt game are less restrictive than in the PD game. As Duncan Snidal suggests, a convention, rather than a contract or legal binding, is likely to be enough for states to realize that it is in their best interests to work together. ${ }^{27}$ Therefore, the Stag Hunt is also called the "assurance game," in which assurance information, rather than an enforcement mechanism, is needed to resolve the collective action problem.

\section{The Game of Chicken-Territorial Disputes}

The game of Chicken is an anti-coordination game. A simple story is that two players drive at each other on a narrow road. The first to swerve loses face among his peers and will be called "chicken" (coward). If neither swerves, however, they will crash and die. The payoff matrix is shown in Figure 4.

Figure 4 shows that the worse outcome for both drivers is to stay until the two cars crash and both die (-IOO, -IOO). If they choose different strategies, i.e., one stays, the other swerves, then the one who stays will be better off (I) and the one who swerves will lose face (-I). If they both swerve, then both will become "chickens," but they will not laugh at each other (o, o). There are two pure Nash equilibriums in which each driver prefers a different optimal strategy, i.e., if driver I chooses to swerve, then driver 2 will stay, and vice versa. ${ }^{28}$ The game of Chicken is also called an "anti-coordination game." Unlike the Stag Hunt game in which both hunters have the incentive to choose the same strategy, the two drivers in the game of Chicken will be better off by choosing different strategies. Therefore, the two drivers have the incentive not to cooperate.

The game of Chicken is more likely to take place under the conditions of low strategic uncertainty and high conflict of interest. First, both drivers

27. Duncan Snidal, "Coordination Versus Prisoner's Dilemma: Implications for International Cooperation and Regimes," American Political Science Review 79:4 (December 1985), pp. 923-42.

28. There is also a mixed strategy in the game. 
FIGURE 4. The Game of Chicken under Low Uncertainty and High Conflict of Interest

Driver 2

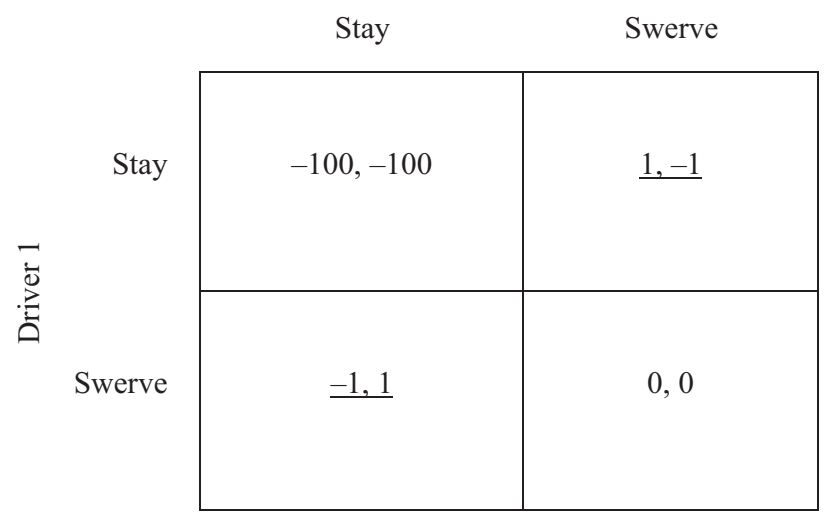

SOURCE: Ibid. to Figure 3.

NOTE: The two pure Nash equilibriums are underlined.

know that they will die if they crash. It is the worst outcome: both want to avoid it. It is a clear and certain situation. From the payoff matrix, we can see that the payoff for "die" is -Ioo, and the payoff for "lose face" is only -I. The huge difference between these two payoffs indicates a clear preference (strong certainty) for both drivers. Second, it is a high conflict-of-interest situation because they do not share any interest to either both stay $(-\mathrm{IOO},-\mathrm{IOO})$ or both swerve (o, o). There are two pure Nash equilibriums, in which they choose different strategies.

The logic of the game of Chicken can be found in territorial disputes in world politics. On the one hand, two states with a disputed territorial claim know exactly what the other party wants to do. It is a low uncertainty situation. On the other hand, the conflict of interest between the two states is high because sovereignty is exclusive in nature. Applying the game of Chicken to territorial disputes, we have to assume that no state wants to go to war because war is a costly and inefficient outcome for both states. ${ }^{29}$ In reality, domestic politics, nationalism, or even bargaining failure may drive states into unwanted war. Therefore, the game specification is just to simplify

29. James Fearon, "Rationalist Explanations for War," International Organization 49:3 (Summer 1995), pp. 379-4I4. 
the rational logic of territorial disputes rather than to provide a concrete explanation of any specific event.

In a territorial dispute or the game of Chicken situation, both states have the incentive to do what the other does not do. It means that if one party knows that the other will stay, it will swerve to avoid a possible collision. However, since there are two possible equilibriums, it is hard to say which party will win out before the game ends. In order to win the game of Chicken, a driver needs to show his resolve and convince the other driver that he will not swerve. In a territorial dispute, each state has an incentive to signal the other party that it will not compromise. Therefore, the key to winning the game of Chicken or a territorial dispute is to increase the credibility of signaling.

In the game of Chicken, one driver can throw his steering wheel out of the car in order to show the other driver that he has no way to swerve. In a territorial dispute, one state can use a strategy of "sinking cost" to send a costly signal to the other party. ${ }^{30}$ For example, one state can conduct an expansive, large-scale military exercise near the disputed territory to show its resolve to the other country. Since the cost of a military exercise is unrecoverable, it is the "sunk cost" the country is willing to pay in order to deliver its credible signal. ${ }^{31}$ In practice, stronger powers have more advantages than small ones in a territorial dispute because the more power the state has, the more resources it can use to signal its resolve.

The role of institutions is limited in the game of Chicken, for two reasons. On the one hand, institutions can do little to strengthen the credibility of a state's signaling. Instead, the involvement of institutions may reduce the credibility of a state's resolve. For example, if a state seeks help from the U.N. on a territorial dispute, this behavior can be interpreted as a sign of weakness by the other party. Seeking help from the U.N. indicates that this state cannot cope with the challenge by itself in a realist world. On the other hand, institutions normally cannot help states solve high conflict-of-interest issues, such as sovereignty disputes between nations. Institutions can facilitate states' exchange of information about their intentions as well as possible consequences. However, as mentioned before, the strategic uncertainty is low in

30. Thomas Schelling, The Strategy of Conflict (Cambridge: Harvard University Press, 1960); and James Fearon, "Signaling Foreign Policy Interests: Tying Hands Versus Sinking Cost," Journal of Conflict Resolution 4I:I (February 1997), pp. 68-90.

3I. In addition, military exercises can also play a deterrent role in territorial disputes. 
territorial disputes because both states know exactly what the other wants and what will happen if no one compromises. In other words, merely using the information clearance process through institutions is not sufficient to resolve the zero-sum game between two states in territorial disputes.

One possible role of institutions in the game of Chicken is to encourage both players to choose to swerve. In territorial disputes, it means to let both states choose to keep the status quo. Although retaining the status quo is not the optimal choice for both players compared to the two Nash equilibriums, as we just discussed, both states are still better off than the worst outcome of war (a crash, in the game of Chicken). It is worth emphasizing that in order to perform this function, institutions should be highly institutionalized with a strong enforcement mechanism. In other words, both states should be ensured by the institutions that no state will take advantage of the other. In an anarchic world, this is difficult to achieve due to the lack of overarching authority in the system.

Power instead of institutions will be the final solution in territorial disputes. A weaker state, if deterred by a stronger power's signaling, can decide to change course in the disputes, just like swerving in the game of Chicken. In addition, since the weaker state faces more relative costs than the stronger one, it is also rational for the weaker state to "swerve" before the conflict starts. Ceteris paribus, the more power a state has, the higher the possibility it is for the state to win a territorial dispute.

\section{The Battle of the Sexes-International Trade Negotiations}

The Battle of the Sexes is another coordination game similar to the Stag Hunt game. It says that a husband and wife have agreed to go out to attend an entertainment event at night. Unfortunately, they cannot communicate at the moment, and neither of them remembers which of the two special events in town they had agreed on, the boxing match or the opera. The husband prefers the boxing match while the wife prefers the opera; yet, both prefer being together to being apart. The payoff matrix is shown in Figure 5.

We can see that both husband and wife will be better off to go to the same event $(2, \mathrm{I})$ or $(\mathrm{I}, 2)$ because if they do not, they will get zero payoffs for both (o, o). There are two pure Nash equilibriums, similar to the Stag Hunt game. However, differing from the Stag Hunt game, husband and wife have different payoffs in these two equilibriums. If both of them go to the boxing 
FIGURE 5. The Battle of the Sexes under Low Uncertainty and Low Conflict of Interest

Husband

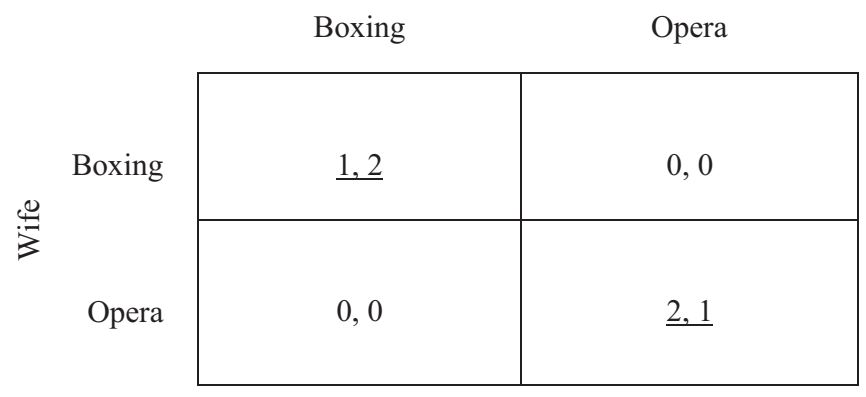

SOURCE: Ibid. to Figure 4 .

NOTE: The two pure Nash equilibriums are underlined.

match, the husband will be happier that the wife (2, I). If both of them go to the opera, the wife will be happier than the husband $(\mathrm{I}, 2)$. The different payoffs make it difficult for the couple to reach an agreement.

This Battle of the Sexes game is shaped by two strategic factors: low uncertainty and low conflict of interest. First, both husband and wife know that they will be worse off if they are not together. The payoff for them to choose different strategies is (o, o). In comparison, one hunter may still catch a rabbit if he chooses not to cooperate with the other to hunt a stag. Therefore, the uncertainty between husband and wife is lower than that in the Stag Hunt. Second, the level of conflict of interest is low since both husband and wife share a common interest to stay together, just as in the Stag Hunt.

In international politics, international trade negotiations follow the logic of the Battle of the Sexes game. On the one hand, states know they will be better off to cooperate in promoting international trade and liberalizing their markets because free trade will benefit their society. However, the benefits from trade are not equally distributed between nations. Some countries may gain more than others, just as with the different payoffs for husband and wife in the game. The difficulty in trade negotiations is not to convince two countries that trade is good for them, but to let both countries reach an agreement with discrepancies in the benefits from trade distributions.

Unlike in the Stag Hunt game, institutions play a limited role in facilitating states' cooperation in international trade. Institutions can certainly 
provide information and increase transparency about how good trade cooperation will be for states. However, this will also make the two states more aware of the different distributions from trade. More important, institutions can do little to resolve this distribution problem between the two states. The iterated game of the Battle of the Sexes will not resolve the distribution problem either. Instead, it may worsen the distributional discrepancy between the two states from international trade. In other words, the increasing volume of international trade will not reduce, but will enlarge, the distributional differences between the two states.

However, if an institution is led by a hegemon, the situation may be different since the hegemon can play a "judge" role to reallocate the benefits from trade among states inside the institutions. We see this phenomenon in the post-war multilateral trade systems, such as the General Agreement on Tariffs and Trade (GATT) and the World Trade Organization (WTO), in which the U.S., the hegemon, played a leadership role in promoting global trade liberalization. It is true that the current multilateral trade system is seen by many as a public good that the U.S. provided to the world. However, it is also the truth that the U.S. has benefited the most from the system. ${ }^{32}$

Therefore, institutions may be useful to solve the distribution problem in trade. One condition is that institutions should be led by a strong hegemon that can enforce and even alter the distributions of benefits from trade, just as the U.S. did after World War Two. However, when U.S. leadership in the WTO is no longer dominant or is challenged by others, multilateral trade negotiations tend to stall, as we can see from the failure of the Doha Round.

As with the game of Chicken, power instead of institutions is more useful for states to solve the distribution problem in a coordination game. In his classic work on global communications regimes, Stephen Krasner points out that the regime did not matter in order for states to solve coordination problems with distributional consequences. Instead, the asymmetric power between states is the key to settling some global communications problems, such as radio broadcasting and remote sensing. ${ }^{33}$ Trade, just like global communications, is a coordination game with uneven distributional benefits

32. Robert Gilpin, Global Political Economy: Understanding the International Economic Order (Princeton: Princeton University Press, 200I).

33. Stephen Krasner, "Global Communications and National Power: Life on the Pareto Frontier," World Politics 43:3 (April 199I), pp. 336-66. 
for different states. In a trade negotiation, a stronger state will enjoy more advantages to force the weaker one to accept a deal that the stronger prefers.

Although the weaker state does not desire for this scenario to happen, it sometimes has to accept the reality that its bargaining power is also weaker. From a weaker state's perspective, an uneven distributional gain is still better than no gain at all if no trade agreement is reached. Therefore, it is also rational for a weaker state to accept a sub-optimal outcome in trade negotiations, just like the situation of the Battle of the Sexes, in which either husband or wife will have to compromise in order to avoid the worst outcome. Another solution is also possible if the stronger state voluntarily provides the weaker state a higher payoff in trade negotiations. This kind of trade cooperation will be much easier than the first solution, but the stronger state may have other agendas behind its apparent compromise in trade.

If the power distribution is symmetrical (no hegemon), an institution may help to alleviate or resolve the distribution problem between the two states in international trade. The two states can reach an agreement that they will alter the distributional gain in the iterated games. Institutions can help states to reach such an agreement. As in the Battle of the Sexes game, the couple can reach an agreement that if they go to the opera this time, the next time will be the boxing match. In the iterated game of the Battle of the Sexes, a reciprocal agreement can make both husband and wife happy. In international trade negotiations, such a reciprocal agreement can be also reached between states with similar economic clout. However, this kind of reciprocal agreement may be fragile because no authority (hegemon) monitors its implementation. Cheating by one party will easily kill the deal.

\section{THE CASE OF THE ASIA PACIFIC-WHAT INSTITUTIONS CAN DO AND WHAT THEY CANNOT DO}

A strategic functional theory of institutions suggests four typical strategic situations (or games) for states in international politics: the Prisoner's Dilemma, the Stag Hunt, the game of Chicken, and the Battle of the Sexes. This paper argues that institutions do not always matter in these four situations. As mentioned, this strategic functional theory of institutions is a middle-range theorization, which specifies under what conditions institutions matter in world politics in general. It does not rule out the role of other variables, such as norms and identity, in shaping state behavior in specific 
regional settings. Therefore, the theory provides a parsimonious model to evaluate different functions of institutions in world politics, which can be a starting point for stimulating intellectual dialogue among different schools of thought.

In the Asia Pacific, this model can shed some new light on how to evaluate the effectiveness of ASEAN and ASEAN-centered institutions. Instead of praising or criticizing Asian regionalism led by ASEAN in general, we should assess the successes and failures of ASEAN's institutions based on different issue areas. This analysis suggests that institutions do not matter all the time on all issues. Therefore, it is unfair to expect that ASEAN-centered institutions can address all the political, economic, and security challenges in the Asia Pacific. For example, the strategic functional theory of institutions suggests that institutions play a minimal role in resolving territorial disputes between states. If this is the case, then we should not expect too much from ASEAN and ASEAN-centered institutions in resolving or even alleviating the South China Sea disputes between China and several Southeast Asian states.

The best that ASEAN-related institutions can do is to convince all the parties in the disputes to maintain the status quo. However, once the territorial disputes have flared up, institutions are more likely to lose power. In other words, ASEAN and ASEAN-centered institutions are not designed to have the function to resolve the South China Sea disputes in the first place. Thus, the ARF's slow evolution from confidence building to preventive diplomacy is not a surprise. ${ }^{34}$ The expectation of building conflict resolution measures in the ARF also seems unfounded. Therefore, it is unwise or unrealistic for policy makers to push ASEAN in particular and ASEAN-related institutions in general to resolve the South China Sea disputes. It is also unfair for scholars to use the South China Sea disputes to discredit the role of ASEAN and Asian regionalism in the Asia Pacific.

By the same token, ASEAN's failure in promoting multilateral trade agreements is also not a surprise, according to strategic functional theory of institutions. This is because trade negotiations follow the logic of the Battle of the Sexes situation, in which the distribution problem is the major hindrance for states' cooperation. The stalled ASEAN Free Trade Area (AFTA)

34. Takeshi Yuzawa, "The Evolution of Preventive Diplomacy in the ASEAN Regional Forum: Problems and Prospects," Asian Survey 46:5 (September/October 2006), pp. 785-804; Ralf Emmers and See Seng Tan, "The ASEAN Regional Forum and Preventive Diplomacy: Built to Fail?" Asian Security 7:I (February 20II), pp. 44-6o. 
vindicates the limited role of institutions in promoting multilateral trade negotiations in Southeast Asia. Moreover, the proliferation of free trade agreements between ASEAN states and some major powers is hardly seen as a success of institution-building in the region. Instead, it is a result of power dynamics and strategic competitions among great powers, especially China, Japan, and the U.S., in the Asia Pacific.

It is clear that institutions are by no means useless in promoting trade in the Asia Pacific. However, strong leadership is required. Just as the successful economic integration of the EU mainly benefits from German and French leadership, Asia also needs an "economic hegemon" that can lead the regional trade negotiations and economic integration. Economically, ASEAN seems too weak to lead. The strategic competition among China, the U.S., and Japan, however, discourages any country from playing the economic leadership role in Asia. Therefore, even if we want to blame someone for the unsuccessful multilateral trade cooperation, the target should be the great powers, not ASEAN states.

ASEAN has played a significant role in promoting cooperation among states on non-traditional security issues since the end of the Cold War. As the strategic functional theory of institution suggests, multilateral institutions can help states deal with the coordination problem presented by nontraditional security problems. There are three types of institution-building led by ASEAN in handling non-traditional security issues. First, ASEAN promotes intra-regional cooperation among its members. For example, under the 1997 ASEAN Declaration on Transnational Crime, the Association has held an ASEAN Ministerial Meeting on Transnational Crime (AMMTC) every two years, to coordinate the activities of the ASEAN Senior Officials on Drug Matters and the ASEAN Chiefs of National Police (ASEANAPOL). An "ASEAN Plan of Action to Combat Transnational Crime" was adopted in June 1999. In January 2010, an ASEANAPOL Secretariat was also established. The latest AMMTC was held in Vientiane, Laos, in September 2013.

Second, ASEAN encourages bilateral cooperation between it and outsider powers on non-traditional security issues. One successful story is ASEANChinese cooperation. In 2002, ASEAN and China signed a Joint Declaration on Cooperation in the Field of Non-Traditional Security Issues, in which both parties pledged to combat "trafficking in illegal drugs, people smuggling, sea piracy, terrorism, arms smuggling, money laundering, international 
economic crime and cybercrime." ${ }^{35}$ Some scholars suggest that nontraditional security cooperation between China and ASEAN "may be seen as part of the most advanced and comprehensive working model of regionalism in East Asia." ${ }_{36}$

The third type of institution-building is ASEAN-centered regional cooperation, especially with other regional and international organizations, such as the U.N., in the field of non-traditional security. For example, after the 2004 Indian Ocean tsunami, ASEAN called for further regional cooperation on humanitarian assistance and disaster relief. In July 2005, ASEAN members signed the ASEAN Agreement on Disaster Management and Emergency Response through which ASEAN members shall "earmark to help each other in times of disaster emergency." More importantly, ASEAN has expanded the cooperation on humanitarian assistance and disaster relief to a wide regional level through the ARF framework and other regional and international organizations. In May 2009, the first ARF Voluntary Demonstration of Response on Disaster Relief exercise was held in Central Luzon in the Philippines. In 20I3, Thailand and the Republic of Korea co-hosted the third ARF Disaster Relief Exercise in Cha-am, Phetchaburi, Thailand, which aimed to strengthen the coordination and disaster relief mechanisms in the Asia Pacific. The key participants of this event included the ASEAN Coordinating Centre for Humanitarian Assistance on disaster management (AHA Centre), the United Nations Office for the Coordination of Humanitarian Affairs (UNOCHA), and the International Red Cross and Red Crescent Movement, the world's largest humanitarian network. ${ }^{37}$

Obviously, these institution-building efforts are not necessarily equalled by the effectiveness of ASEAN in dealing with non-traditional security issues. As some scholars point out, regional responses and cooperation on non-traditional security threats, such as illicit trafficking and abuse of drugs, epidemic disease, and terrorism, are still premature or face many

35. See "Joint Declaration of ASEAN and China on Cooperation in the Field of Non-Traditional Security Issues," Phnom Penh, November 4, 2002.

36. David Arase, "Non-Traditional Security in China-ASEAN Cooperation," Asian Survey 50:4 (July/August 20IO), p. 833 .

37. ASEAN Secretariat News, "ASEAN Regional Forum Gears Up for a Stronger Civil Military Coordination and Disaster Relief Operation," May I3 20I3, <http: http://www.asean.org/news/aseansecretariat-news/item/asean-regional-forum-gears-up-for-a-stronger-civil-military-coordination-anddisaster-relief-operation>, accessed July I6, 2014. 
hindrances. ${ }^{38}$ However, ASEAN's institution-building has at least signified the first step in coping with non-traditional security issues in the Asia Pacific. How to improve the efficiency and effectiveness of ASEAN-centered institutions on non-traditional security should be the top priority of Asian regionalism in the future.

Last, but not least, given their non-binding institutional structure and consensus-based decision making process, ASEAN-centered institutions have limited power in dealing with traditional security issues, such as arms races among states in the region. Some scholars have pointed out that defense expenditures of Asian countries have dramatically risen since the I997 economic crisis. ${ }^{39}$ The most worrisome issue is that Asia's weapons acquisition patterns, such as the proliferation of submarines, have shown that states are preparing for externally oriented conflicts. ${ }^{40}$ In other words, a region-wide arms race has been on the horizon in the Asia Pacific. Although it is absolutely rational for states to strengthen their military capabilities, this research suggests that institutions can help states cooperate to avoid the worst outcome of arms race.

However, the prerequisite is that the institutions should be equipped with strong binding mechanisms to enforce agreements and punish cheating behavior between states. The ASEAN Way and the consultative nature of ASEAN-centered institutions apparently cannot match this expectation. How to gradually develop some binding mechanisms to alleviate regional arms races is the most challenging task, if not a mission impossible, for ASEAN and ASEAN-centered institutions in the 2Ist century.

38. Mely Caballero-Anthony, "SARS in Asia: Crisis, Vulnerabilities, and Regional Responses," Asian Survey 45:3 (May/June 2005), pp. 475-95; Jonathan Chow, "ASEAN Counterterrorism Cooperation since 9/II," ibid., 45:2 (March/April 2005), pp. 302-2I; Ralf Emmers, "International Regime-Building in ASEAN: Cooperation against the Illicit Trafficking and Abuse of Drugs," Contemporary Southeast Asia 29:3 (December 2007), pp. 506-25.

39. Robert Hartfiel and Brian Job, "Raising the Risks of War: Defence Spending Trends and Competitive Arms Processes in East Asia," Pacific Review 20:I (March 2007), pp. I-22.

40. Sam Bateman, "Perils of the Deep: The Dangers of Submarine Proliferation in the Seas of East Asia," Asian Security 7:I (February 20II), pp. 6I-84. 